ERATO 八島超構造らせん高分子プロジェクト中間評価報告書

研究総括 :

八島 栄次【名古屋大学大学院工学研究科/教授】

研究体制：

人エらせん構築グループ (クリエイション・コア名古屋)

らせん機能開発グループ (クリエイション・コア名古屋)

バイオらせん構築・情報グループ (クリエイション・コア名古屋)

らせん誘起・記憶ユニット (名古屋大学大学院工学研究科)

評価委員 :

彌田 智一【東京工業大学資源化学研究所/教授】

○遠藤 剛【近畿大学分子工学研究所/副所長 - 教授、東京工業大学名誉教授】

中濱 精一【産業技術総合研究所・臨海副都心センター／研究コーディネーター、 東京工業大学名誉教授】

原田 明【大阪大学大学院理学研究科/教授】

藤木 道也【奈良先端科学技術大学院大学/教授】

(○は主査)

1 . 総合評価 $($ : 評価の概要 $)$

評価 : 秀 (Excellent)

ERATO 八島超構造らせん高分子プロジェクトでは、戦略目標「非侵襲性医療シス テムの実現のためのナノバイオテクノロジーを活用した機能性材料・システムの創製」 のもと、高分子がつくるコホメーションのうち「らせん」に着目し、人工的な「らせ ん」構造のデザインと構築を目指している。关の根底には一見すると DNA の二重らせ

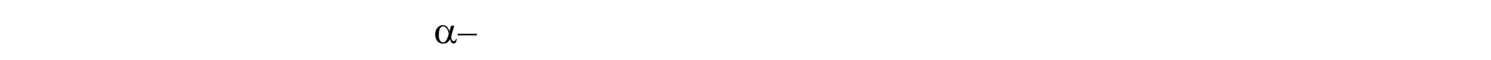
あるが、実際には光れを超えたところに普遍的な「らせんの本質」を見出し、弚の合成、 構造解析、機能発現を追究することに目標を定めている。すなわち、「新規物質群の設 計・創成・諸物性・新機能発現」ならびに長年直接観測が非常に困難であった「らせん 構造の可視化、高分子 1 本鎖の動的振舞」を明らかにすることにより、DNA 等が有し 
ている生命機能の本質を理解し、構造や機能を模倣し、果ては光れらを凌駕することを 狙いとしたものであり、ERATO の理念に則った、極めてチャレンジングかつ目標設定 の高いプロジェクトであると言える。

本プロジェクトは、3つのグループ (人工らせん構筑、らせん機能開発、バイオら せん構築・情報）と、弚れらを束ねてグループ間の情報交換を進めるユニット（らせん 記憶・誘起) から構成される。八島総括の本務先である名古屋大学とは別の場所 (クリ エイション・コア名古屋) に主体となる研究実施場所を設け、自由な雰囲気と総括への 求心力とか調和した研究体制を敷いている。このオフキャンパスでの研究サイトの立ち 上げにおいては、施設の整備や装置の搬入等とも関連して、円滑な研究推進に相当の時 間を要したようであるが、現在は光れを克服し、各グループリーダー・研究員の個性を 活かした柔軟なプロジェクト運営が随所に見られる (毎週 1 回の研究討論は、グループ ごとに分けることなく、従って「縦割り」的なものではないとのことである)。

本プロジェクトは各グループの鋭意検討に加えて、グループ及びユニット間の効果 的な連携によって進捗している。すなわち人工らせん構筑、らせん機能開発、バイオら せん情報・構築の各グループでは、研究総括および各グループリーダーが開拓してきた 超構造設計と合成、原子間力顕微鏡 (AFM) 観察手法、液晶構造構筑の知見と技術を 生かして連携しつつ研究を展開し、結果として独自性の高い優れた業績を举げている。 弚の証拠として、プロジェクトでの成果の全てが、Journal of the American Chemical Society (JACS)、Angewante Chemie International Edition (Angew. Chem.) など一流の学術杂隹 誌に掲載され、また夋の成果のいくつかは、Science、Angew. Chem.の Editor's Choiceや Highlight に選ばれるなど、この中間評価の時点における成果としては高い水準に達して いると評価したい。さらに中間評価会 (2006 年 2 月 13 日) においては、論文未発表の 成果についての説明があつたが、いずれも間もなく著名な学術誌に投稿、掲載されるも のと期待できるものであった。一方特許はこれまでにバイオらせん情報・構筑グループ から 7 件出願されているが、残る研究期間では、事務方のサポートを得つつ、人工らせ ん構筑グループやらせん機能開発グループから、あるいはグループ共同による特許出願 も積極的かつ戦略的になされることを望みたい。

いずれにせよ、名古屋大学時代以来ここ 10 年あまりにわたって、八島研究づルー プ (一部は、岡本佳男・現名古屋大学エコトピア科学研究所教授と共同で推進されたも のである)か培った知識とノウハウは、本 ERATO プロジェクトにも発展的に活かされ、 発足後 3 年が経過した段階でのプロジェクトにおける研究は、順調に進んでいると評価 したい。一方評価委員としては、新たな物質・機能の探索、あるいはらせん高分子でな いとできない機能を見出すことは、「らせんの本質とは何か」と言う、「サイエンスとし て重要なものを探究し続ける」重要な課題ではあるものの、現在までの主たる成果のう ちいくつかに的を絞り、乥こに研究員を注力することか望ましい、とも提言したい。ま た残された研究期間においては、「応用味のある高分子材料創成の可能性を見出す」こ 
とにも取り組んでもらいたい。いずれにせよ評価委員は一致して、八島研究総括がグル ープ横断的なテーマの推進ならびに研究員の育成と出口を考えながら、彼らの研究テー マの発展を考えて指導力を発揮し、世界に冠たる本 ERATO プロジェクトからの大きな 成果と多数の優れた人材の輩出を切に願っている。

\section{2 .評価の詳細（：進捗状況と今後の見込み）}

本 ERATO プロジェクトが、常に質の高い研究成果を発信する、非常にアクティビ ティの高い研究グループであることは衆目の一致するところである。ここでは、現在ま での研究成果等に対する評価委員の所見を述べつつ、さらなる質の高い研究成果を挙げ てもらうための提言を与えたい。

\section{（1）人工らせん構築グループ}

本グループは、新規ならせん高分子、らせん超構造分子の合成を研究の主軸とし、 中でも新しい分子設計に基づく多重らせん構造の合成に挑戦している。本グループの成 果が、構造解析や機能探索等を推進する他の 2 つのグループにも波及すると言う点でも、 重要な役割を担っている。

产の研究成果のハイライトは、相補的な二重らせん構造の超分子をオリジナルな物 質群から構築することに成功したことである。アミジンとカルボン酸との塩橋反応とい う組み合わせを用いて、らせん分子の単体を構築し、光れをらせん高分子の構筑にも発 展させた成果は、大変高く評価できる(なおこの成果は Science、Angew. Chem.の Editor’s Choiceや Highlight に選ばれた)。また現在未発表ながら多くのファミリーか設計・創製 されており (中間評価会において発表)、今後の発展を感じさせるものである。さらに、 $\pi$ 共役系オリゴフェニレンの一重-二重らせん構造の創製にも成功した点も、評価でき る点であると言える。共役系オリゴフェニレンは光も光も物質系として、光・電気・磁 気機能が期待できるものであり、八島総括が築き上げたらせん高分子化学におけるポリ フェニルアセチレン系 (1995 年) に続く次世代の研究対象となる可能性を持っている。 今後、さまざまな分野の研究者が結集することを望みたい。

これらの成果は従来のへリケートとは異なり、相補的な認識部位を持つ二重らせん 構造を人工的に創出した初めてのものであり、相補的分子認識に基づく「人工 DNA 型 超分子」として究極の分子認識システム実現を予感させる。オリゴマー化や機能ユニッ 卜の導入など合成化学的アプローチによって、超分子化学の一領域を築くことを期待さ せる一方、生体系における DNA の作用を人工系で模倣するだけにとどまらず、乥れを 凌駕するものか望めるかを、今後の研究展開を模索する上で熟考して欲しい。 
上記のように、本グループは質の高い顕著な成果を上げているのは間違いない。光 の上で今後の研究展開の戦略設定は重要である。さらなる多種多樣ならせん高分子、多 重らせん高分子等の設計と合成を継続し、合成化学としての成果を蓄積していくことは 重要かも知れないが、「らせんの本質とは何か」「柔軟ならせんを制御する」ことを明 らかにするのが、プロジェクトの主たる研究目標であることを鑑みると、プロジェクト 内外の研究グループとの連携を一層強めて、グループ自体が主体的に取り組む対象を絞 り込むことにも柔軟に取り組んで欲しい。中間評価会でも発表がなされていたような、 これまでに見出された物質系を対象とした、触媒機能や情報機能の探索・発現・制御は 非常に重要な課題であると考えるので、本グループの寄与を期待したいところである。

（２）らせん機能開発グループ

本グループは、らせんモジュールを用いた分子認識機能や触媒作用の発現を目標に、 らせん構造の直接観察、らせん高分子の 2 次元・ 3 次元配列制御などに取り組もうとし ている。現在はらせん構造の観察と 2 次元制御の段階であり、精密ならせん構造観察 制御の結果からも、新たな研究展開が生まれてくるものと期待する。

本グループでは、卓越した AFM 観察技術を用いることによって、らせん高分子の 絶対的巻き方向やらせんピッチ長、凝集構造の解明、及び高分子単分子鎖の分子運動の 可視化に成功している。つ数年前まで、DNA の二重らせんですら、AFM で見ること は困難であったことを考えると、合成高分子の形成するらせん構造を可視化することは より困難なことであることは容易に想像され、従って本グループの取り組みは高く評価 できるものである。また、合成高分子単分子鎖の基板上での分子運動の直接観察におい ては、AFM 探針の応力による分子の応答と高分子鎖本来の熱運動をどのように分離で きるかを検討しており (Macromolecules 39, 1209 (2006))、この取り組みにも評価を与え たい。以上の取り組みは、高分子全般の表面構造を分子レベルで直接観察する方法論と して、今後のソフトマテリアルの研究開発に新たな貢献も期待させる。

これらの研究成果を通して、「直接見る」ことの重要性は強く認識させられた。乥 の一方で、何を見ているのか及び、弚こからどのような展開か拓けるかを常にイメージ しておくことも重要であることを付け加えたい。例えば、AFM 観察を通して高分子鎖 と種々の基板との吸着や化学結合にも研究の焦点を当てることが、このグループが例え ば触媒機能等の探索へと研究を展開する際に、大変重要な知見をもたらすことへとつな がるのではないだろうか。

（３）バイオらせん構築・情報グループ 
本グループは、他のグループの発足よりも 1 年以上遅かったにもかかわらず、新し く光して興味深いらせん液晶構造を見いだす成果を挙げている。主な成果は、水中での キラルドーパントによるポリアセチレン誘導体コレステリック液晶創製、光学活性側鎖 を有するポリアセチレン液晶相と非常に長い持続長の発現、および炎れら液晶構造の制 御を挙げることができる。今後も、らせん体の液晶相形成と光の構造変化を自由に制御 出来る研究を推進して頂きたい。炎こにはらせん構造の「柔軟さ」に基づく外部刺激に 対する敏感性があり、「らせんの本質とは何か」を明らかにする重要なキーとなるであ ろう。

一方、グループの名称にも含まれている「バイオ」については、DNA-タンパク質 複合体 (RecA) をテンプレートとする金属ナノワイヤーの作製が、主な研究成果とし て挙がっている。生体内では DNA やタンパク質の $\alpha$-ヘリックスなど、あらゆる箇所で 「らせん」が用いられており、「らせん構造を生体はいかに利用しているか」などとい った、「らせんの本質は何か」というテーマに迫ることができる研究系であると言える。 例えば、RecA 複合体による多重らせん間の高分子鎖の巻きなおし機構は、バイ才分野 からの「らせんの本質的機能」を解明する手がかりとなる研究として意義があると思わ れ、まさに光こにこ炎他の 2 グループで扱われている「人工らせん高分子」が、今後参 考にできる「らせんの本質」が潜んでいるかも知れない。見出された現象を利用して、 電子デバイスへの応用を検討することも確かに魅力的ではあるが、一方で、グループの 根底を流れる大きな概念とプロジェクト全体の中での位置づけを示しうるストーリー 性を考えることも、必要であると感じる。

（４）らせん誘起・記憶ユニット

本プロジェクトの研究構想の根幹を成す「人工らせん高分子によるらせん誘起・記 憶」に関しては、八島総括が 10 年来築いてきた研究領域であり、すでに現時点で学術 的に高い評価を得ている。同ユニットがプロジェクトの「ハブ」としての役割を担い、 各グループの拠り所となる組織を構成していることは高く評価できる。

水溶液中におけるらせん誘起や記憶保持したらせん構造の複製、らせん構造の保存 と記憶など、八島総括の構想を強力に推進しており、世界で他の追随を許さない領域へ と展開している力強さを感じる。高分子の配座構造の中で規則的ならせん配座に着目し、 無限に近い自由度を巧妙な分子認識と協同効果によって、「誘起」「保持」「記憶」「複 製」などを厳密に実証している。高分子の動的な溶液内構造を対象にした、こうした研 究の取り組みは類が無く、高く評価されるべき点である。

このように「らせん誘起・記憶」の概念を明らかにしてきたことは、本プロジェク 
トの重要な成果のひとつであり、今後の展開では今までの実績を積み上げつつ、「記憶」 や「情報」の諸現象を発現している物理化学的背景を深く理解することによって、概念 のさらなる一般化と拡張がなされることを期待したい。

以上か評価を踏まえた今後への提言であるが、現在までの数多くの優れた成果をべ ースとして、総括および研究員らがこの時期に深く議論することによって (場合によっ てはプロジェクト内でのテーマの選択や集中、及び/あるいは他のグループとの連携強 化を図ることによって)、残る期間でのプロジェクト研究が力強く光して効率よく推進 されることを望みたい。本中間評価および提言が兴の際の参考となると共に、プロジェ クトで得られる成果が、やがては「今後の新しい科学技術の流れを生み出す」という ERATO の趣旨に則ったものとなれば、大変喜ばしい限りである。

以上 